\title{
The intellectual challenge of doing bioethics in South Africa
}

\author{
A Egan, BA Hons, MA, MDiv, STL, PhD \\ Steve Biko Centre for Bioethics, Faculty of Health Sciences, University of the Witwatersrand, Johannesburg, South Africa \\ Corresponding author: A Egan (anthegan2@gmail.com)
}

\begin{abstract}
Contemporary bioethics is a complex and multidisciplinary combination of medicine, philosophy and law, made more difficult because few, if any, bioethicists are masters of all three disciplines. To further complicate matters, each discipline contains specialised subdisciplines and internal debates. Philosophy is used to illustrate this point. Given constraints of expertise on practising bioethicists in South Africa, a few modest proposals are suggested to make bioethics as a discipline more rigorous in its use of medicine, philosophy and law.
\end{abstract}

S Afr J Bioethics Law 2017;10(1):8-10. DOI:10.7196/SAJBL.2017.v10i1.535

How do we make medical moral judgments as practising bioethicists? Do we simply follow the prescriptions of law and professional codes of practice; do we start with the best available medical knowledge and act accordingly; or do we ask in the light of law and science what is the right thing to do? Our starting point tells us a lot about who we are as bioethicists. It may also highlight the problems facing the teaching, learning and practice of the discipline today.

Although bioethics is now a compulsory component of South African (SA) medical education, having previously been something of a 'Cinderella' subject in most faculties in the past, it is by no means clear that students, professors and professionals in healthcare know what to make of it, or indeed how to do it. This is at least in part due to the nature of bioethics' necessarily complex mixture of philosophy, law and medicine - each of them disciplines that require years of study for mastery, and each of which is subject to its own internal debate.

Most working bioethicists enter the field through one of these three disciplines. Although they acquire knowledge of the others, how they do bioethics will reflect their starting point. However, a philosopher will gain a working knowledge of medical law and the basics of medicine in order to be effective. Similarly, a lawyer will need to acquire broader skills in philosophy as well as jurisprudence and basic medicine. And a healthcare professional will need more legal knowledge than medical law, and to develop a solid grounding in philosophy. (Those who come from outside these fields - sociology, history or theology, for example - will have to do comprehensive study in all three to get on board.)

To further complicate things, within each core discipline there are many different approaches to the subject that sometimes compete and sometimes complement each other. Legal theory (jurisprudence) is often split between an approach that emphasises interpretation and application of laws, and a profound scepticism about the hidden or not-so-hidden interests and ideologies behind a given law. Health science education, too, has hidden curricula: claims of empirical, observable truth following a scientific experimental method combined with a realisation, at least since Thomas Kuhn, ${ }^{[1]}$ that intuitions can result in paradigm shifts; and certain ideological worldviews about the nature of care (prevention or cure) and access to it (public or private health). Philosophy is even more complex, and to illustrate my general point let me try, through a (necessarily) simplified history, to illustrate the point I am making in detail.

Philosophy is an intellectual family of subjects - epistemology, metaphysics, logic, politics, mind and ethics, to name a few - bound together by reason. Done properly, they interlink with each other: you cannot really reflect ethically unless you have a clear understanding of the nature of ethics (metaphysics) and how you know something is right (epistemology), based upon a coherent argument (logic). To further complicate matters, philosophising is often done - since the 19th century at least - within two broad traditions that have, until recently, barely spoken to each other: the analytic and continental schools.

This split between the traditions emerged out of a response to Kant's theory of knowledge. Kant ${ }^{[2]}(1724$ - 1804) held that some things can be known by our experience of them (the phenomenal) while others cannot: they can be known only in themselves (the noumenal). Hegel (1770 - 1831) $)^{[3]}$ denied the distinction, arguing that both subsisted within what he called the Ideal. While Hegelian thought in various forms dominated European philosophy (and often applied in theology) until the early 20th century, it was challenged from a variety of perspectives.

In Denmark, Kierkegaard ${ }^{[4]}$ (1813 - 1855), a Lutheran theologian at odds with a Church he considered too conformist to his society, objected to Hegel's claim that thought could be objective, insisting that truth was subjective - the truth of a fact (for example, a Christian doctrine) lies in one living it out, not simply in its logical coherence or reference to reality. Similarly, the German Nietzsche ${ }^{[5]}$ (1844 - 1900) reacted against any Hegelian application of the Idea to religion (and against religion in general), and developed his own subjective theory of self-mastery (the Ubermensch). These ideologically divergent thinkers would form the basis for the 20th-century existentialism of thinkers as varied as Heidegger, Jaspers, Sartre and Camus. ${ }^{[6]}$ Together with phenomenology, drawn as the word implies at least in part from Kant's idea of the phenomena, it would be a major component of continental philosophy, ${ }^{[7]}$ which would expand to include the postmodern thinking of philosophers such as Derrida and Foucault. 
Continental philosophy's interests generally lay - lie - within the 'big picture': movements of history, the working of institutions, the nature of religion and belief, literature and ethics. Its breadth of scope often leads it into dialogue with other disciplines: history, sociology, theology, literature and art. Critics may well object that it is in fact these disciplines and not philosophy. (I remember a philosopher in London objecting bitterly to Kierkegaard being taught as a philosophy elective: 'He's a bloody theologian!' he snorted.)

These critics usually come from the analytical philosophical tradition ${ }^{[8]}$ which emerged as another revolt against Hegel in the early 20th century, mainly at the universities of Cambridge and Vienna. Rejecting the possibility of Kant's noumenal and Hegel's synthesis, they insisted on an epistemology based on the truth of evidence. Central to this, and played out in various ways, was the emphasis on truth claims referring to what can be objectively discovered. Since what many analytical philosophers prized above all was evidence, there was a tendency to look into the finer details of things, drawing heavily on logic and philosophy of language to establish verifiable truths.

Quite quickly these philosophical traditions took on geographical associations: while continental thought dominated mainland Europe and Latin America, analytical philosophy had as its base Britain (and by extension universities in the British 'Empire') and North America. This distinction is somewhat muddied by the existence of a more continental tradition in religiously founded universities, notably Catholic universities and seminaries, where, since the Middle Ages, philosophy has been integrated into the study of theology.

Within SA, faculties at historically English-speaking universities usually work within the analytical school, while Afrikaans universities more often lean towards the continental. ${ }^{[9]}$ These differences, despite a current tendency to greater dialogue between them, and growing integration of philosophers in them working together in the same departments, affect how philosophers approach questions of bioethics.

This is within what we call the Western tradition that has dominated academia during the centuries of European-North American global power. Beyond this we see a range of Eastern philosophies that have persisted for centuries, and now vibrant traditions emerging from Africa. These too are gaining traction in SA.

What does this mean for bioethics in SA today? Firstly, it is clear that bioethicists coming to the field primarily from philosophy are probably coming in with one or other of the dominant Western philosophical traditions. This all-too-brief account of them shows that differences in content and method exist, and have an effect on the conclusions bioethicists make. There is nothing wrong in that: divergent opinions are the lifeblood of academic discourse. Agreeing to disagree is a sign of maturity and a careful corrective to mental rigidity.

But, secondly, what is important is to note how this affects bioethicists from other primary disciplines. Those whose fields emphasise objectivity, empirical data and 'facts' may be frustrated by such divergent opinions - particularly those emanating from people of the continental tradition. Similarly, those whose primary interest is to know what the law commands may question the point of such speculation - until of course there arises a need to change laws. At the very least, thirdly, we may find ourselves talking at cross-purposes.

There is an even deeper risk: superficiality. The great English philosopher of history, Collingwood ${ }^{[10]}(1889-1943)$, warned against what he called 'scissors and paste' history. By this he meant 'excerpting and combining the testimonies of different authorities', having already concluded what one wanted to know about a subject. The mere act of cobbling together bits of 'evidence' (I suppose in the age of computers we might more accurately call the process 'cut and paste'), without asking the underlying question why?, often results in at best a narrative, at worst a half-baked bricolage of statements. As a historian I agree with Collingwood that such a method is unsatisfactory; it is equally unhelpful in bioethics.

How many of us, I wonder, haven't come across student essays or even academic papers that are little more than a string of quotes and a conclusion? One sees citations of laws ('The National Health Act says ... so ...'), sweeping appeals to ethical theory ('From the theory of deontology, it seems ... so ... ) or to principles ('The principle of autonomy says ... so ... ) or claims based on medical evidence ('From the medical fact that ... so ... ). My instinctive response to such statements is often, "So ... what?" Without careful engagement with law - whether taking the cited law as a starting point and then either working through its possible application, if not also engaging in the background, intentions and ideological assumptions behind law that are central to critical legal theory - the conclusion is usually shallow. Without insight into the origins, internal controversies and critiques of a philosophical theory, its application is too easily facile (and certainly unsatisfactory to any professional philosopher). And without accepting that most medicine is based on best currently available evidence, often subject to ongoing and further experimental research, informed at times by paradigm shifts in thinking, one might come across as having a fixed understanding of science. A contemporary medical practitioner whose thought is rooted in Aristotelian biology would be laughed out of court by peers - and considered dangerous to patients.

At bottom, it is a question of academic rigour. The problem I have illustrated above reminds me of trying to hold water in leaky buckets. One can of course arrange one bucket within another (and so on, theoretically ad infinitum) in a sequence such that water runs out more slowly. It is conceivable that one might even manage, through careful arrangement, to minimise leakage, but the leak will remain. Does this mean that any ethical reflection - where law is subject to development or change, medical knowledge is constantly evolving and philosophy is almost by definition a constantly evolving set of arguments - is impossible?

I don't think so. The classical-medieval philosophical and theological idea of probabilism offers us a way forward here. ${ }^{[11-13]}$ Essentially a guide to making a moral judgment when conflicting strong arguments coexisted, probabilism describes a continuum of moral reasoning - from laxism at one extreme to tutiorism at the other. Laxism effectively suggests that one could act so long as one had a reason (however thin); tutiorism holds that one should always take the morally 'safest' side, usually identified with positions of the highest authorities (which in medieval terms meant popes and councils of the Catholic (Church). Neither extreme position is intellectually satisfactory, but in-between the extremes there are positions that offered (and offer) a fruitful approach. Probabiliorism (from the Latin, 'more likely') argues that one should adopt a position that had a preponderance of evidence on its side. Equiprobabilism, occupying the centre of the continuum, argues that all things being 
equal, one could take a less safe option if it was as good as, or very close to, the safe option. While some might see all this as medieval hair-splitting, what it offers makes sense to ethicists who admit that, in the light of limited knowledge of law, medicine and philosophy, the best we can do is to present provisional moral arguments as coherently as possible, while having the epistemological humility to recognise that we may not have solved a problem for all time: we've arranged our buckets together in such a way that we have minimised the leaks.

Such sophistication and epistemological humility is vital for the further growth of SA bioethics as both an academic discipline and as a practice in healthcare. But, as I have argued, the level of complexity of its components makes the goal difficult to attain, particularly when they are not the sole focus of its practitioners.

What, then, can be done?

Broader and deeper education for bioethicists is obviously needed. Specialised programmes of study (such as the University of the Witwatersrand MSc in Bioethics and Law, for example) are a good start, although even here there may need to be a more expanded curriculum. What may be needed is more jurisprudence, so that bioethicists understand the nature of law more fully, in addition to the specifics of medical law; some introduction to the different forms of philosophy, particularly differing epistemologies, in addition to ethics; and even perhaps some philosophy of science and the scientific method.

Given the limits - time, resources, costs, etc. - of any formal programme, and given that many practising bioethicists may not even be able to engage in further specialised studies, the least we can perhaps hope for is ongoing personal study in the areas I have mentioned above. To make this easier, more systematic and less lonely, one possibility is setting up informal cross-disciplinary reading groups for bioethicists.

While this may seem a nuisance, I think it may be necessary. Bioethics is more than intellectual speculation. At bottom, it's often about people's lives.

1. Kuhn T. The Structure of Scientific Revolutions. Chicago: University of Chicago Press, 1962.

2. Kant I. Critique of Pure Reason. Cambridge: Cambridge University Press, 1999.

3. Hegel GWF. Phenomenology of Spirit. Oxford: Oxford University Press, 1977.

4. Kierkegaard SA. Concluding Unscientific Postscript to Philosophical Fragments. Princeton, NJ: Princeton University Press, 1992.

5. Nietzsche FW. Thus Spake Zarathustra [1883]. London: Penguin: 2003.

6. Crowell S. (ed.). The Cambridge Companion to Existentialism. Cambridge: Cambridge University Press, 2012.

7. Kearney R. Continental Philosophy in the 20th Century. London \& New York: Routledge, 2012.

8. Schwartz SP. A Brief History of Analytic Philosophy: From Russell to Rawls. Hoboken, NJ: Wiley-Blackwell, 2013.

9. Millar S, MacDonald I. The Role of Philosophy in South Africa. New York: Berghahn Books, 1989.

10. Collingwood RG. The Idea of History (revised edition). Oxford: Oxford University Press, 1994.

11. Franklin J. The Science of Conjecture: Evidence and Probability before Pascal. Baltimore: Johns Hopkins University Press, 2001.

12. Maryks RA. Saint Cicero and the Jesuits: The Influence of the Liberal Arts on the Adoption of Moral Probabilism. London \& New York: Routledge, 2008.

13. Schüssler R. On the anatomy of probabilism. In: Kraye J and Saarinen R, eds. Moral Philosophy on the Threshold of Modernity. Dordrecht: Springer, 2005:91-113. 